\title{
Need for better adherence to optimal incubation temperature for quality laboratory diagnostics and antibiotic resistance monitoring
}

\begin{tabular}{|c|c|}
\hline \multicolumn{2}{|c|}{$\begin{array}{l}\text { Authors: } \\
\text { Cristina Gutierrez }^{1} \\
\text { Akos Somoskovi } \\
\text { Kris Natarajan } \\
\text { David Bell } \\
\end{array}$} \\
\hline \multicolumn{2}{|c|}{$\begin{array}{l}\text { Affiliations: } \\
{ }^{1} \text { Independent consultant, } \\
\text { Vigo, Spain }\end{array}$} \\
\hline \multicolumn{2}{|c|}{$\begin{array}{l}{ }^{2} \text { Global Health Technologies, } \\
\text { Global Good Fund, } \\
\text { Intellectual Ventures } \\
\text { Laboratory, Bellevue, } \\
\text { Washington, United States }\end{array}$} \\
\hline \multicolumn{2}{|c|}{$\begin{array}{l}\text { Corresponding author: } \\
\text { Cristina Gutierrez, } \\
\text { crisgupe1@gmail.com }\end{array}$} \\
\hline \multicolumn{2}{|c|}{$\begin{array}{l}\text { Dates: } \\
\text { Received: } 13 \text { Feb. } 2018 \\
\text { Accepted: } 26 \text { July } 2018 \\
\text { Published: } 06 \text { Dec. } 2018\end{array}$} \\
\hline \multicolumn{2}{|c|}{$\begin{array}{l}\text { How to cite this article: } \\
\text { Gutierrez C, Somoskovi A, } \\
\text { Natarajan K, Bell D. Need for } \\
\text { better adherence to optimal } \\
\text { incubation temperature for } \\
\text { quality laboratory diagnostics } \\
\text { and antibiotic resistance } \\
\text { monitoring. Afr J Lab Med. } \\
\text { 2018;7(2), a789. https://doi. } \\
\text { org/10.4102/ajlm.v7i2.789 }\end{array}$} \\
\hline \multicolumn{2}{|c|}{$\begin{array}{l}\text { Copyright: } \\
\text { C) 2018. The Authors. } \\
\text { Licensee: AOSIS. This W } \\
\text { is licensed under the } \\
\text { Creative Commons } \\
\text { Attribution License. }\end{array}$} \\
\hline \multicolumn{2}{|l|}{ Read online: } \\
\hline 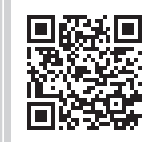 & $\begin{array}{l}\text { Scan this QR } \\
\text { code with your } \\
\text { smart phone or } \\
\text { mobile device } \\
\text { to read online. }\end{array}$ \\
\hline
\end{tabular}

In the omics era, incubation of human specimens and bacterial cultures continues to be the cornerstone for detection, identification and drug susceptibility testing (DST) of bacterial pathogens. Accurate results require bacterial incubation under optimal physicochemical conditions. Temperature is a key physicochemical factor that affects the bacterial environment, making incubators indispensable in clinical laboratories. Human pathogens generally multiply best at temperatures similar to those of the human host $\left(35^{\circ} \mathrm{C}-37^{\circ} \mathrm{C}\right)$. Biochemical tests for identification in pure isolates are recommended to be performed at $36^{\circ} \mathrm{C} \pm 2{ }^{\circ} \mathrm{C}$, and DST at $35^{\circ} \mathrm{C} \pm$ $1^{\circ} \mathrm{C} .1,2,3,4$ For Mycobacterium tuberculosis complex and most nontuberculous mycobacteria, the recommended temperature is $37^{\circ} \mathrm{C}$ in both cases.

In a recent survey to determine the incubator requirements for clinical microbiology laboratories in resource-limited countries, we analysed several parameters including the temperatures used to incubate clinical specimens for primary bacterial isolation, replicating bacterial cultures and performing DST. The data were reported in a self-administered questionnaire conducted from April 2017 to June 2017 by 12 laboratories from three countries in Africa (Cameroon, Ivory Coast and Madagascar), three countries in the Americas (Haiti, Guyana and Bolivia) and one country in Asia (Bangladesh). The clinical specimens considered were sputum, pharyngeal or nasopharyngeal swabs, stools, urethral or vaginal swabs, skin, pus, urine, lymph nodes, blood, bone marrow, cerebrospinal fluid and other normally sterile body fluids. The analysed incubation temperatures referred to 26 pathogenic bacteria or pathogenic bacteria groups frequently isolated from clinical specimens (Figure 1).

Laboratories working with mycobacteria incubated both specimens and isolates at the appropriate temperature of $37^{\circ} \mathrm{C}$ for $M$. tuberculosis complex and nontuberculous mycobacteria, or at $30^{\circ} \mathrm{C}$ in the case of Mycobacterium ulcerans.

To target the other 24 bacteria or groups of bacteria, specimens were incubated for primary isolation at either $35^{\circ} \mathrm{C}$ or $37^{\circ} \mathrm{C}$ with a tendency towards $37^{\circ} \mathrm{C}$. Laboratories employed the same distribution of temperatures for sub-culturing isolates and performing DST, with the exception of one laboratory sub-culturing Acinetobacter baumanii, Salmonella typhi and Salmonella paratyphi at $42^{\circ} \mathrm{C}$. The reported temperature fluctuation during incubation was $\pm 2{ }^{\circ} \mathrm{C}$ for $55 \%$ of the incubators, $\pm 1^{\circ} \mathrm{C}$ for $29 \%$, and $\pm 3^{\circ} \mathrm{C}$ for $16 \%$.

Clinical laboratories are often faced with the need to grow a priori unidentified bacteria and potentially polybacterial specimens from non-sterile sites. To best support recovery of bacterial pathogens, as well as biochemical testing and DST incubation requirements, a temperature of $35^{\circ} \mathrm{C}$ is likely ideal. At $35^{\circ} \mathrm{C}$, most human bacterial pathogens with differing optimum growth temperature will grow reliably, although colonies may appear small or require additional incubation due to their slower growth rate. ${ }^{5} \mathrm{DST}$ is recommended to be performed at $35^{\circ} \mathrm{C} \pm$ $1^{\circ} \mathrm{C} .{ }^{3,4}$ The use of $37^{\circ} \mathrm{C}$ by most laboratories puts the reliability of DST results in question. Incubation at $37^{\circ} \mathrm{C}$ also risks fluctuations to dying off temperatures.

Our field survey revealed fundamental failures regarding basic and easy-to-control requirements of incubation that could negatively impact DST, and therefore the battle against antimicrobial resistance. It is difficult to assess the real magnitude of the problem, because this study relied on self-reported laboratory procedures, which may be subject to bias. With the growing importance of identifying isolates and trends of antibiotic-resistant human pathogens, it is alarming that the simplest global recommendations fail to reach the workplace. More rigorous attention must be paid to bacterial incubation, including DST requirements, through the institution of evidence-based protocols and use of quality instruments that can provide accurate 


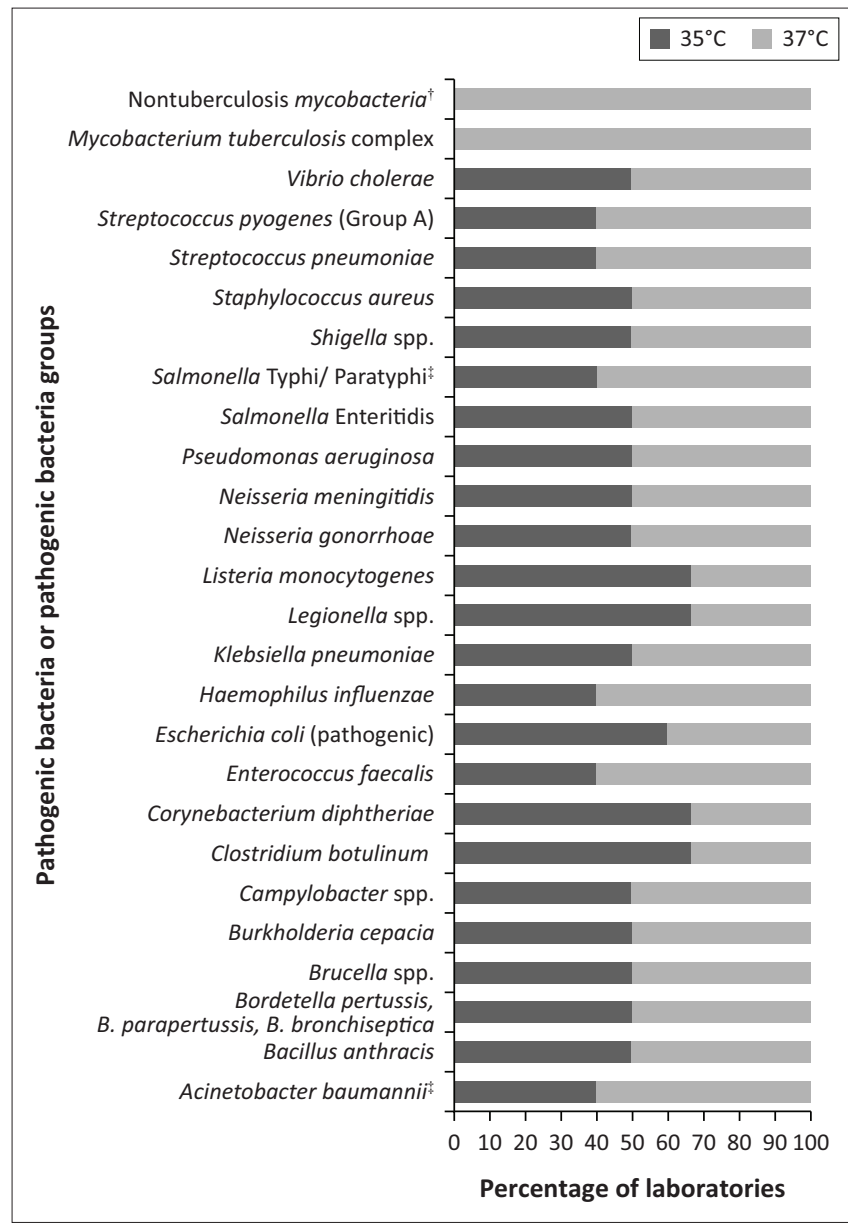

DST, drug susceptibility testing.

$\dagger$ Except Mycobacterium ulcerans which was incubated at $30^{\circ} \mathrm{C}$; $₫$, One laboratory subcultured Acinetobacter baumanii, Salmonella Typhi and S. Paratyphi at $42^{\circ} \mathrm{C}$.

FIGURE 1: Incubation temperature in 12 laboratories from seven countries for isolation, subculture and DST of 26 pathogenic bacteria or pathogenic bacteria groups frequently isolated from clinical specimens. temperature levels, as well as operating under appropriate quality assurance practices and with stricter adherence to existing guidelines.

\section{Acknowledgements}

\section{Competing interests}

The authors declare that they have no financial or personal relationships that may have inappropriately influenced them in writing this article.

\section{Sources of support}

None.

\section{Authors' contributions}

C.G., A.S. and K.N. designed the project. D.B. made conceptual contributions. C.G. collected and analysed the data. C.G., A.S. and D.B. co-wrote the manuscript.

\section{References}

1. Forbes BA, Sahm DF, Weissfeld AS. Traditional cultivation and incubation. In: Tille P, editor. Bailey \& Scott's diagnostic microbiology. 12th ed. Philadelphia, PA: Elsevier Health Sciences, 2007; p. 93-119.

2. Jorgensen JH, Turnidge JD. Susceptibility test methods: Dilution and disk diffusion methods. In: Murray PR, editor. Manual of clinical microbiology. 9th ed. Washington DC: ASM Press, 2007; p. 1152-1172.

3. The European Committee on Antimicrobial Susceptibility Testing. Disk Diffusion Method for Antimicrobial Susceptibility Testing - Version 6.0. EUCAST, European Society of Clinical Microbiology and Infectious Diseases: Basel, Switzerland; 2017.

4. Matuschek E, Brown DFJ, Kahlmeter G. Development of the EUCAST disk diffusion antimicrobial susceptibility testing method and its implementation in routine microbiology laboratories. Clin Microbiol Infect. 2014;20:0255-0266.https://doi. org/10.1111/1469-0691.12373

5. Winn W, Allen S, Janda W,et al. Phases of the diagnostic cycle: Analytical phase. In: Koneman EW, editor. Color Atlas and textbook of diagnostic microbiology. 6th ed. Baltimore, MD: Lippincott Williams \& Wilkins, 2006; p. 15-42. 